\title{
CONSIDERING AL-GHAZALI'S PHILOSOPHY THINKING AUTHORITY
}

\author{
Teguh Purnomo Putra \\ Institut PTIQ Jakarta, Indonesia \\ E-mail: teguh.torres09@gmail.com
}

\begin{abstract}
The reputation and authority of al-Ghaza li in Islamic thought has had a profound influence as well as is controversial and ambivalent. His character covers almost all scientific disciplines in Islam. In the field of philosophy, the response to his thinking generated controversy that lasted for centuries. On the one hand, he is assumed to be a central figure for the decline of Islamic thought, especially philosophy, and is considered the most successful thinker in positioning philosophy proportionally in the Islamic world on the other. This paper discusses the philosophical thinking of al-Ghaza li, his criticisms of the thoughts of previous philosophers, and responses to his thoughts in the hope that they can provide conclusions that are quite "fair" and proportionate in positioning al-Ghazali in the islamic philosophy discourse.
\end{abstract}

Keywords: al-Ghazali; Philosophy

Abstrak. Reputasi dan otoritas al-Ghazali dalam jagad pemikiran Islam memiliki pengaruh yang begitu besar sekaligus kontroversial dan ambivalen. Ketokohannya meliputi hampir seluruh diskursus disiplin keilmuan dalam Islam. Dalam bidang filsafat, respons terhadap pemikirannya menuai kontroversi yang beralangsung berabad-abad. Satu sisi ia diasumsikan sebagai tokoh sentral atas kemunduran pemikiran dalam Islam, terutama filsafat, dan dianggap sebagai pemikir yang paling sukses dalam memposisikan filsafat secara proporsional dalam dunia Islam di sisi lain. Tulisan ini membahas tentang pemikiran filsafat al-Ghazali, kritik-kritiknya terhadap pemikiran filosoffilosof sebelumnya, dan respons terhadap pemikirannya dengan harapan bisa memberikan kesimpulan yang cukup "adil" dan proporsional dalam memposisikan al-Ghazali dalam diskursus filsafat Islam.

Kata Kunci: al-Ghazali; Filsafat

Permalink/DOI: https://doi.org/10.15408/mimbar.v38i1.24183 


\section{Introduction}

When discussing the upheavals and developments of thought in the Islamic world, particularly in the field of philosophy, the name Al-Ghazali (d. $505 \mathrm{H} / 1111 \mathrm{AD}$ ) should come to mind. An Islamic thinker who has the skills and expertise in many scientific fields. Inevitably, from his multi-discipline, Al-Ghazali later received a number of academic titles such as theologian, jurist, Sufi, and, perhaps the only one of the many Islamic thinkers, hujjatul Islam. Moreover, Al-Ghazali is also considered as a mujaddid (Ahmed Serif, 1975: 1). The title mujaddid itself is based on the hadith of the Prophet which explains that on every century, Allah will send a mujaddid in religious matters (Abu Dawud, 1935: 424). Therefore, Al-Ghazali's authority in the world of Islamic thought is still resonates until today. Even Mc. Donald equalize Al-Ghazali, in his world of thought and influence, with Augustus and Aquinas in the Christian world. (Krarneaers, 1953: 40)

In the study of philosophy, Al-Ghazali's thinking on the one hand received a very large appreciation from Islamic orthodoxy because it was considered able to put philosophy proportionally in Islamic studies but it also received criticism from other parties who had concerns in the world of philosophy, especially when Al-Ghazali sharply criticized the two previous philosophers; Ibn Sina and al-Farabi (Aristotelian). Al-Ghazali's sharp criticisms of the incoherence of the thoughts of Ibn Sina and al-Farabi was manifested specifically in his monumental work entitled Tahafut al-Falasifah (Hourani, 1959: 227 \& Watt, 1952). : 44). Furthermore, after diligently studying philosophy, he then developed his own philosophy work called Maqasid al-Falasifah (Hourani, 1959: 227 \& Watt, 1952: 44).

The influence of Al-Ghazali's philosophical thought, at a later stage, also stimulated the emergence of assumptions from many circles that his criticism of philosophical thought has actually made Islamic thought decayed for centuries, especially regarding the fact that philosophical studies in Islam has been in decline for quite a long time. Even some circles, in viewing Al-Ghazali, make an analogy of the book Tahafut al-Falasifah as a vaccine while Ihya' Ulum al-Din acted as an "anti-dote" which because of its great influence, had been able to cure the "chronic disease" suffered by the people at that time. However, because of over-dose, instead of being effective for people in the next era, it was then caused various more acute diseases by paralyzing other organs and paralyzing them for a long period of time (Abdullah, 1995: 130).

The stigma against Al-Ghazali even today also seemed to get its justification when there are many institutes and colleges consider "taboo" and affected by a "historical trauma" in conducting an active and lively study of philosophy. The study of philosophy is still existing nowadays, although it is quite rare and the theme is often only about classical philosophy.

Based on the discussion above, this paper is intended to review and analyze Al-Ghazali's philosophical thoughts with the purpose of providing a "fair" and proportional conclusion in positioning Al-Ghazali in the center of philosophical thought.

\section{Al-Ghazali's View of Philosophy: Tracing the Epistimology of Al-Ghazali's Critique of Philosophy}

Before coming to the section on Al-Ghazali's criticism of the thoughts of Muslim philosophers, this paper will begin its discussion on Al-Ghazali's views to philosophy. This, according to the author, is 
very crucial to be used as a starting point in an effort to understand Al-Ghazali's independence in philosophy as well as the scope of his criticism of philosophy.

Tracking the objectivity of Al-Ghazali's thoughts and criticisms of philosophy can be done by revealing his independence in constructing his thoughts. As it is widely known, during these times AlGhazali experienced a spiritual crisis on the one hand and intellectual crisis on the other which became famous as the event of doubt (al-syakk/skeptic). The acute doubt that afflicted him was caused by his enthusiasm for achieving absolute truth (al-'ilm al-yaqin). Therefore, in order to fulfill this desire, AlGhazali then traced almost all scientific disciplines and carried out investigations on them, from the discipline of kalam to philosophy. However, what must be understood, as explicitly stated by AlGhazali, is that objectivity in assessing a thought can only be achieved by, first of all, studying and analyzing the thought itself. So that in the final stage, the assessment is not just a subjective claim without an adequate background understanding of it (Al-Ghazali, 1971: 3 \& Dunya, 1971: 10).

And that is why Al-Ghazali wrote;

"One cannot deconstruct a system of thought without a deep background of understanding it by elaborating each of its fundamental principles” (Al-Ghazali, 2000: 10).

Moreover, the most authentic evidence of Al-Ghazali's mindset above, especially in the field of philosophy, is his Maqashid al-Falasifah which contains Al-Ghazali's philosophical thoughts from the results of his studies on philosophy. This book has been translated into several languages and some Western thinkers at that time considered this book as a summary of Al-Ghazhali's genuine thoughts on philosophy (Muckle, 1933).

Furthermore, Al-Ghazali started his investigation of philosophy by classifying philosophy into three important parts. First, the followers of atheism (al-Dahriyyun); this group is a group of philosophers who deny God who rules this universe and oppose His existence. They have a strong suspicion that nature has existed by itself without God's intervention. They believe that animals came from sperm and sperm came from animals, from ancient time and will forever remain that way. According to Al-Ghazali they are the kind of people who do not know God. Second, the followers of naturalism (al-Thabi'iyyun); they are a group of philosophers who after a long time researching the wonders of animals and plants (nature or tabi'ah) and witnessing the signs of God's power, then finally they acknowledge His existence. However, because they had conducted too many research about nature, they were impressed with the biological nature of animals that had given an influence on their sensory powers. As a result, they argue that the human thinking power depends on his biological character, and when his biological character is lost, so does his thinking power. In the end, they perceived that it is impossible to bring back something that has been lost. They believe that people who have lost their souls will not return. In addition, they also oppose the existence of the hereafter, heaven, hell, the Day of Judgment, and the day of reckoning (yaum al-hisab).

Third, the adherents of the philosophy of God (Ilahiyyun); they are a group of philosophers who believe in God, most of them are Greek philosophers such as Socrates, Plato and Aristotle, as well as people who follow their thoughts. The Ilahiyyun group basically denies the first two groups, which are al-Dahriyyun and al-Thabi'iyyun. Al-Ghazali further stated that Aristotle in the next phase rejected and strongly refuted the views of Plato and Socrates and their predecessors who followed the philosophy of divinity so that he was out of their scope. Unfortunately, in his philosophy, he still leaves some small things that at least still contain indications of disbelief that he has not been able to get rid of. From that 
point of view Al-Ghazali convicted the infidels, including the Islamic philosophers who were inspired by the views of Aristotle such as Ibn Sina and al-Farabi. This group opposes the opinion of the first group such as Socrates, Plato, and Aristotle and the followers of Muslim philosophers such as Ibn Sina and al-Farabi. From these three variants, the criticism of Al-Ghazali's philosophy is focused on the third group (al-Ilahiyyun) (Al-Ghazali, tt: 43-45 \& Sheikh, 1963: 593).

Meanwhile, Al-Ghazali classified the branch of philosophy into six parts: (1) Mathematics, (2) metaphysics, (3) Logic, (4), Physics (Al-Ghazali, 2000: 10-11). He further stated that of the four branches of Philosophy, the Metaphysics has the greatest potential of falsification. Therefore, according to Al-Ghazali, an intense investigation and research must be carried out in this area.

Al-Ghazali's strong criticism in Tahafut al Falasifah (Incoherence of the Philosophers) which goes to the two symbols of Islamic authoritative philosophers at that time (Ibn Sina and al-Farabi) well known as "the famous and most reliable philosophers in Islam", found a logical inaccuracies, inconsistencies, and contradictions on the philosophers thought, that have resulted several mistakes in broad range of aspects. In this case, as stated by Majid Fakhry, Al-Ghazali took the right step by first classifying the controversy among philosophers into three parts, each of which later contained its own consequences and implications (Majid Fakhry, 1997).: 81).

First, the controversy in the matter of language (linguistics). As the controversy regarding the naming of the creator of nature by, some of them, calling Him as essence (jauhar) based on their interpretation that an essence is something that exists (maujud) but is independent, i.e. exists and stands on its own that does not need a place. (al-qaim binafsihi al-ladzi la yahta ju ila maqum yaqumuhu). With this understanding, for Al-Ghazali, this is a section that does not require an overly intense study because basically it does not conflict with religious principles. Al-Ghazali continued by stated that the study of God's attributes in the theological discipline but not in the fiqh discipline, this issue does not have to be debated longer as it is only a matter of articulation (al-talaffuzh) and has not yet reached the essence of the problem. Second, the part which is basically science is not in a direct contact with religious principles. For example, the controversy related to the occurrence of a lunar and a solar eclipse. According to Al-Ghazali, this problem should become the focus of the study of mathematics and astronomy. Thus, it is also not something that should debated. Likewise, the controversy regarding the shape of the earth which some say that it is round while some other say that it is elliptical, and so on. However, as long as the interpretation does not have implications for the belief that the earth is qadim and still believes in it as something new (hadith) then it is legitimate. The third is the part that is closely related to religious principles. Such as the denial of the philosophers of the novelty of nature (huduts al'alam), the attributes of God (sifat al-shani), and physical awakening (hasyr al-ajsad wa al- abdan). Therefore, as explained by Al-Ghazali, this section must be analyzed and clarified critically and in detail to reveal the errors of the philosophers' thinking (Al-Ghazali, 1996: 79-81).

The description above shows, at least, that Al-Ghazali's critique of philosophical thought, as will be described in the next section, does not make it completely suppress philosophy, even though in his criticism he uses the framework and procedures of philosophical thinking. Therefore, the writer tends to see Al-Ghazali's criticism as a philosophical critical reasoning. In addition, Al-Ghazali's intense criticism of philosophy is not aimed to all parts of philosophy but only to the metaphysical aspect. The reason, of course, is that this section is closely related to the principles of religion which, in the investigations carried out by Al-Ghazali, the philosophers often bypassed them radically based on empirical facts resulting from the work of his philosophical thought. This also indicates that Al- 
Ghazali's critique of philosophy is an effort of determination between philosophy and religion, especially in parts where, according to him, have a weak philosophical reasoning and thus unable to reveal the truth. In addition, perhaps, Al-Ghazali's criticism can also be considered as a new epistemological offer in philosophical thought with an integration pattern between religion (theology) and philosophy.

\section{Al-Ghazali's opposition to the philosophy of Ibn Sina and al-Farabi in Tahafut al-Falasifah}

In the following, we will briefly outline the 20 philosophical issues criticized by Al-Ghazali with two assumptions; philosophers are often inconsistent and contradictory in demonstrating their philosophical thinking and the weakness of philosophers in demonstrating rational arguments in reasoning about the essence and existence of God and its relationship with nature.

\section{Refutation of the views of the philosophers about the eternity of nature}

In the first discussion of various objections to philosophers, which are described in the form of dialogue writings, it can be found four topics related to this, namely, the qadim of nature, the eternity of nature and time, Allah as the Creator and the Designer of Nature, and the inability to prove the existence of a natural maker. Here Al-Ghazali refuted Ibn Sina's theory of emanation. For Al-Ghazali Nature is something new (hudust) and begins from the qodim that is the only one, Allah (Al-Ghazali, 1996: 88-123).

\section{Refutation of the theory of eternity (abadiyah) of nature, time and space}

According to philosophy, material (things), mass (time), and space all emerge at the same time. Time is a measurement of the time distance from material and space is where the material is existed. For philosophers, material is eternal (perhaps the same as the eternity of energy in physics). Al-Ghazali denies this idea, for him if Allah wish to destroy nature and abolish it ( $i^{\prime}$ dam) then this Nature is surely destroyed and there will be nothing left. (Al-Ghazali, 1996: 124-133).

The confusion of philosophers in explaining that God is the creator of nature and nature is

his creation, and the statement that this is a majaz (parable) and not its essence

Here, Al-Ghazali's criticism is more on the opinion of philosophers who say that God is characterless. Also, if Allah is the creator as we know so far, then the creator must first will (murid), choose (mukhtar), and know what he wants. So that God becomes a fa'il (doer) of what He wills. Furthermore, for philosophers, God is not a willful being (disciple) because will is an attribute while God is a pure essence of all attributes. And something that arises from Him is a necessary consequence (luzum dlaruri).

The second thing for philosophers that is impossible because nature is qadim and fi'il (actions) is new (hadith). Third, God is one and does not arise from it except one and nature is murakkab (composed) from many aspects. So, according to the philosophers, how can something murakkab (composed) arise from one thing? Hence, Al-Ghazali rejected the three things above (Al-Ghazali, 1996: 134-154).

\section{The inability of philosophers to prove God's existence as the creator of nature}

Here Al-Ghazali questions the thesis which states that nature is qadim, but it was created. For AlGhazali, this is a combination of opinions between ahl al-haq who states that nature is hadith, and that hadith must have a creator. While the atheists (Dahriyah) who claim that nature is qadim then it does 
not need a creator. For Al-Ghazali the opinions of these philosophers are automatically invalidated (AlGhazali, 1996: 160-171).

The weakness of philosophers in proposing the rational argument that God is one and the impossibility of having two Gods, wajib al-wujud, each of which has no illat (cause)

Al-Ghazali challenged everything in proving these philosophers. For Al-Ghazali what is rejected is the logic used and not the substance of the problem (Al-Ghazali, 1996: 160-171).

The refutation of the non-existence of attributes for God

For the philosophers, God must be cleansed of all calculations (muta'addidah), including all attributes - which the Ash-'Ariyah people have attached to God. If the nature coexists with God, then there is interdependence between the two. God's dualism is impossible, especially if it is added with af al.

Al-Ghazali rejected this argument, and stated the weakness of the philosophers' opinion about the absence of God's nature. For Al-Ghazali this is rejected because nature is something that must exist in essence but it does not mean it becomes something other than essence (Al-Ghazali, 1996: 172-183).

A refutation to the theory that the essence of God is impossible to define

Philosophers argue that the definition contains two aspects; jins (genus) and fashl (differentia). Meanwhile, God is a substance who cannot make musyarakah in jins and he is not divided into fashl. Both are compositions and God is impossible to compose. For Al-Ghazali it is possible that the composition of the "parts" occurred from a definitive point of view. This is because Al-Ghazali accepts the attributes of God (Al-Ghazali, 1996: 184-189).

Cancellation of the philosopher's opinion: The form of God is simple, meaning that the form of God is a pure form, not mahiyah (the essence of something - al-kautsar) and not the essence on which God's form is based on, but the form of al-wajib like mahiya for the others

Al-Ghazali denies all of these philosophers' analogies both about mahiyah, nature, and form alwajib which according to Al-Ghazali repeats the same confusion. Al-Ghazali questioned all the methods used in generating this thought and considered it a mistake by the philosophers (Al-Ghazali, 1996: 190192).

The inability of the philosopher to prove, by rational argument, that God is not a body (jism)

This departs from the existence of an eternal body (jism qadim) which is accepted by philosophers. This for Al-Ghazali is ambiguous because jism is something that is hadith because it is composed of differences (fashl-fashl). If the philosopher evades by saying that the obligatory al-Wujud is one, then it cannot be divided like the others. This too, according to Al-Ghazali is a forced logic because it departs from the perception of the impossibility of the composition (tarkib) and the rejection of the composition is based on the rejection of mahiyah (quidity) (Al-Ghazali, 1996: 193-195). 
The inability of philosophers to prove through rational postulates the existence of a cause or creation of nature

For Al-Ghazali, this is still a confusion of philosophers who defend the opinion of the qadim of nature but he was created. According to Al-Ghazali why don't they say like the Atheists who say nature is qadim and therefore does not need a creator, because a cause is only needed for things that start in time (hadith) (Al-Ghazali, 1996: 1996-197).

Weaknesses in the opinion of philosophers who say that God knows others and that He knows species (al-anwa) and genera (jins) universally (bi nau'i kulliyat)

The philosophers say that God knows al-anwa' and al-jins in kulliyat because the emanations that occur to them are universal, not individuals.

However, Al-Ghazali gave a rebuttal that God created nature with his will, then nature became the object of the will, it is impossible for the object of the will to be unknown to the willed (Al-Ghazali, 1996: 198-202).

\section{The inability of philosophers to prove that God also knows Himself}

This problem stems from the opinion of philosophers who say that nature emanates naturally, not on a whim, like the emanation of sunlight from the sun. The rebuttal given by Al-Ghazali is that if something that emanates from God knows itself how can God as the origin of the emanation not know Himself, because God is aware of the existence of such emanation, according to His will (Al-Ghazali, 1996: 203-205).

The fall of the philosophers' opinion that God does not know the particulars that can be divided according to the division of time into "has", "was" and "will".

The opinion of philosophers that knowledge follows the object of knowledge, if the object changes, then knowledge also changes, if knowledge changes then the subject also changes. Changes that occur in an object will cause the knowledge of the object to change as well as the subject who knows the change. However, it is impossible for God to change because He does not know the changes that occur in time. Nothing is hidden from His knowledge, but His knowledge of it remains the same, both before a change occurs, is happening or after it occurs. This is Al-Ghazali's argument about it.

Moreover, Al-Ghazali stated that the opinion of the philosophers on this matter contradicts their previous opinion which said that the nature of qadim, something that is qadim cannot be changed. Why did he change? So the philosophers must change their opinion regarding the qadim of nature (AlGhazali, 1996: 206-217).

The inability of the philosophers to prove that the sky is a living being (hayawan), and obey God through its motion.

The sky is a living being and has a soul that relates to the sky's body as our soul relates to our body. This is evidenced by the movement of the sky. The celestial movement is neither a natural movement nor a forced movement (driven by "the other") but a volitional movement (iradi wa nafsani). Regarding this expression, Al-Ghazali stated that the sky is not a living being, because the movement of the sky is a "coercive" movement and the will of God as its principle (Al-Ghazali, 1996: 218-221). 


\section{The refutation of what philosophers stated as the purpose which moves the sky}

The movement of the sky according to the philosophers aims to taqarrub (get closer) to God. The meaning in question is getting closer in terms of attributes, not in terms of space, as the angel's closeness to Him, because He exists as a perfect being different from everything that is not perfect. And the angels who are near (al-muqarrabun) are something that is close to His perfection. The perfection of the sky is obtained through similitude (tasyabbuh) with the first principle through; perfect placement in all possible positions for him.

The refutation given by Al-Ghazali as expressed in the previous issue (14). He added that the movement of the sky does not indicate that they (the sky) aim to approach perfection in the sense of God's perfection, because there is no difference between their position in one place and another which indicates perfection. Everything is just a change of position (Al-Ghazali, 1996: 222-225).

The weakness of the philosophers' theory is that the sky souls know all the particulars that originate (al-juziyyat al-hadtsah) in this world

This problem began when the philosophers said that the heavenly angels were the souls of the sky, who became God's intermediaries in filling al-lawh al mahfuzh. The objection expressed by AlGhazali then is how it is possible for a creature to have knowledge of infinite particulars (juz'iyyat).

Moreover, Al-Ghazali said that the most confusing thing is the statement of the philosophers that if the celestial sphere (falak) has particular movements, it also has a representation of the subordinates and the consequences of that particular movement. Like a moving human being must know his movements and the consequences of his movements in relation to other bodies or other creatures and that is impossible (Al-Ghazali, 1996: 226-238).

The refutation of the philosophers regarding the impossibility of separation from the natural causes of events

According to Al-Ghazali, the relationship that is believed to be cause and effect is not mandatory. All cause and effect relationships occur because God has created them that way. For example, He has the power to create a feeling of fullness without eating, as in the example when Abraham was not burned by fire. This is not possible unless it removes the heat from the fire or God has created a certain quality that can prevent the emergence of an effect from a cause (Al-Ghazali, 1996: 239-251).

The inability of the Philosophers to rationally demonstrate their theory that the human soul is a self-existing spiritual substance; does not occupy space; not the body; and not imprinted in the body; and he is neither related to the body nor separated from it just as God is neither outside the realms nor in the realms and so are the angels

What the philosophers base on in this case is the impossibility of a 'one' and rational knowledge embedded in the body, because if that is the case then the physical sub-stratum must also share that knowledge. Likewise, the soul as a single thing cannot occupy the body which is something that can be divided.

The opinion of philosophers about knowledge as shown in the following syllogism. First, if the sub-stratum of knowledge is a body that can be divided, then the knowledge in it will be divided. Second, the knowledge in it cannot be divided. Third, the substratum is therefore not a body. According to Al-Ghazali, the fault of the philosophers is their understanding of knowledge which will 
be divided by the sub-stratum division. For example, sensory perception (sensory knowledge) as a display of what is perceived in the soul of the person doing the perception where the soul still needs the organs of the body as the senses (Al-Ghazali, 1996: 252-271).

Weaknesses of the philosophers' thesis that once the human soul has materialized it cannot be destroyed; and that his immortal nature makes it impossible for us to imagine his destruction

Al-Ghazali refuted this in two respects; First, in the 18th issue that philosophers have mentioned that the soul does not exist in the body, this has been refuted. Second, although they do not think that the soul exists in the body, it is proven that there is a relationship between the soul and the body, so that a soul depends on the form of the body. The relationship between the soul and the body is a condition for the existence of the soul (Al-Ghazali, 1996: 272-281).

\section{The refutation of the Philosophers' rejection of the resurrection of bodies}

According to Al-Ghazali, religion has taught us to believe in resurrection (al-ba'ts wa al-nusyur) which coincides with the reappearance of life and with resurrection is meant the resurrection of bodies, and this is possible by restoring soul into the body, because it is the soul that forms us even though the body is always changing (Al-Ghazali, 1996: 282-306).

Of the 20 (twenty) issues discussed above, they can be summarized as follows: First. God's relationship with nature, includes problems 1 to 4 , which are: the qadim of nature, the eternity of nature and time, God the Creator and Maker of Nature, and the inability to prove the existence of the creator of nature. Second, oneness and inability to prove Him. -5th problem-. Third, The divinity (God's character). -problems 6th to 12th- fourth, Knowing the little things "juz'iyyat". - 13th issue. Fifth, the problem of astronomy and nature. -problems 14th to 16th. Sixth, cause and effect. 17th problem. Seventh, the human soul. 18th and 19th issues. Eighth, the resurrection of the body on the hereafter. 20th issue.

From the 20 issues discussed, Al-Ghazali considers the philosophers to have become infidels in three issues: the eternity of nature, Allah does not know the particular (juz'iyyat), and the denial of resurrection and the collection of bodies in Judgment Day. Meanwhile, 17 other issues, such as the issue of divine attributes, the creed of monotheism and the necessity of cause-and-effect Al-Ghazali categorize them as heretical.

\section{Responses to the Thoughts of Al-Ghazali: A Portrait of Post-Al-Ghazali Philosophical Struggles}

Tahafut al-Falasifah which covers the criticism of Al-Ghazali even though it is written with an objective and scientific method and epistemology, but its presence in the stage of the struggle of philosophical thought, in the times after that, has sparked quite a reaction. warm' and lasted for a long time among internal Muslims (insiders) and western thinkers (outsiders). There are at least two currents of thought regarding the response and reaction to Al-Ghazali's thoughts above. There are many thinkers who agree and defend Al-Ghazali's thinking, besides there are those who criticize it outright. Ibn Rushd, for example, criticized Al-Ghazali by making three attempts at once, which are defending the philosophers who were disbelieved in Al-Ghazali, clarifying philosophical understanding, and refuting Al-Ghazali's understanding. The defense of the philosophers was carried out by formulating the harmonization of religion and philosophy, the clarification of philosophical understanding was carried 
out by outlining the true meaning of philosophy on matters of disbelief and refutation of Al-Ghazali by elaborating the "error" of his perception. All of this was done by Ibn Rushd by thinking rationally and interpreting religion rationally, but he still adhered to the source of religion itself, which is Al-Qur'an (Rushd, 1964: 361-362). Even for Ibn Rushd, Al-Ghazali's label 'paganism' in criticizing his predecessor philosophers was an attitude that was not fair and too exaggerating (Rushd, 1972: 36-37). Meanwhile, the attitude of Al-Ghazali, according to Ibn Rushd is also contrary to his own thesis in his book Faishal al-Tafriqah baina al-Islam wa al-Zandaqah which explicitly explains that disbelief towards someone because of mere consensus considerations is a tentative attitude. and disproportionate.

Some groups also criticized Al-Ghazali's philosophical thinking specifically thematically of the 20 issues criticized by Al-Ghazali in the book Tahafut al-Falasifah. Like L. E. Goodman who criticizes the issue of causality in Tahafut al-Falasifah. He argues that it is inappropriate if Al-Ghazali is considered to have criticized and undermined the theory of causality built by Aristotle, instead he is more accurately called a person who exploits the concept of causality itself (Goodman, 1978: 83). -120). This opinion was later refuted by Michael E. Marmura in two consecutive articles. According to Marmura, the concept of causality that is 'played' by Al-Ghazali is merely defending the theological understanding of Asya'irah (Marmura, 1981: 85-112. 1989: 46-75, 2005: 145-149). Marmura's opinion was also refuted by Richard M. Frank. In his view, Frank reveals that instead of Al-Ghazali refuting Ibn Sina's thoughts and defending Ash'ari theology, in fact Al-Ghazali's relationship with Ash'ari theology seems ambiguous - not to say open conflict with Ash'arian theology. Asya'irah. The reason was Al-Ghazali's dissatisfaction with the traditional doctrines of Ash'ari theology and finally Al-Ghazali often adopted Ibn Sina's thought as an antidote to his dissatisfaction with Ash'ari theological doctrine (Frank, 1994: 76-80).

With several theses that seem controversial with the results of previous Al-Ghazali researches, Frank's work has initiated the emergence of a 'revisionist' tendency in the study of Al-Ghazali giving a considerable influence on several Al-Ghazali researchers in the world of Ghazalian Studies in the last decade. 1990s. For example, to cite an example, Frank Griffel through his analysis of Al-Ghazali's epitemology with Ash'ari theological doctrine stated that Al-Ghazali, in Tahafut al-Falasifah did not reject Aristotle's theory of causality in total but what he rejected was only a small part., namely the form of the necessity of cause (necessary character) in giving rise to consequences (Griffel, 2009: 149).

Moreover, there are some groups who consider Al-Ghazali as the cause of the stagnation of thought in the Islamic world, especially philosophical studies (DeBoer \& Jones, 1970: 169-171). Amin Abdullah argues that what stands out from the relationship between religion and philosophy is disharmony. This was caused by a deep historical trauma among Muslims with the polemic between AlGhazali and some charismatic philosophers (Ibn Sina and al-Farabi). Until Al-Ghazali's criticism was present on the one hand as a form of confirmation of Islamic orthodoxy and the spirit of philosophical studies on the other (Abdullah, 1995: 117-118). For this group, Al-Ghazali's criticism of philosophy had a tremendous influence on the emergence of a spirit of persecution against philosophy among Muslims. This view may be logical with reference to the fact that Al-Ghazali's authority in the Islamic (Sunni) world is very strong. Therefore, for this group, it is very possible if the decline of Islamic thought, especially post-Al-Ghazali philosophical era was no longer active and even declined for centuries.

However, this view may be overjudging Al-Ghazali's idea by referring to the fact that post-AlGhazali's era, half a century later, in Persia it seems that Tahafut al-Falasifah has encouraged a number 
of scholars to write a book that have the same genre as Tahafut: a refutation of philosophy in general or Ibn Sina in particular. For example, Syaraf al-Din al-Mas'udi (d. 1185) who wrote a book with the title al-Syukuk wa al-Syubah 'ala al-Isyarat. It can be seen from the title that this book is specifically a critique of the doubts (doubts) and ambiguity of Ibn Sina's thought in his work al-Isyarat wa alTanbihat (Shihadeh, 2016). Also, Ibn Ghailan al-Balkhi (d. 1195), al-Mas'udi's student who wrote a critical book to Ibn Sina's philosophical thought about the concept of novelty of nature with the title Huduts al-'Alam (Michot, 1993: 287-344).

Another fact regarding the refutation of the assumption by some scholars that al-Ghazali was the cause of the stagnation of thought in the later era, referring to Cak Nur's analysis, is difficult to deny that al-Ghazali's has given a strong influence to the development of modern thought. Even al-Ghazali's refutation of the theory of the eternal nature of a well-known philosophers, such as Ibn Sina who supported the concept of Aristotelian cosmology, had unconsciously inspired — or at least identicallywith the theory of the "big bang" as the theory of the beginning of nature creation. This proves that nature, contrary to the claims of Aristotle, Ibn Sina, and others, is definitively proven to have a beginning, and came into being from nothing (min al-'adam, min la syay'; ex nihilo) (Madjid, tt: 9$10)$.

\section{Conclusion}

Through the descriptions above, this paper shows that Al-Ghazali's thoughts and criticisms to philosophy are normal in the academic world as long as they are carried out within scientific and objective boundaries. However, borrowing Sulaiman Dunya's term, the understanding of Al-Ghazali's thinking is complete when Al-Ghazali himself can be surpassed. Every thought of Al-Ghazali must always be placed 'proportionally' by exploring the socio-historical-political context that surrounds it. Therefore, this paper only attempts to provide a rough description of Al-Ghazali's philosophical thought and its implications. This paper, of course, again, does not pretend to provide a thorough, detailed, and thorough description. There are many segments that have not been touched. For example, by intensively examining Al-Ghazali's philosophical thoughts thematically and comparing them with his similar thoughts, which may be widespread even though in different intensities in his other works.

The study of Al-Ghazali's philosophical thought can also be expanded by systematically categorizing each theme and analyzing it through comparisons with the thoughts of the figures he criticizes. Or it could also be done in order to test Al-Ghazali's consistency in his thoughts and criticisms of philosophy as he also often seems to adopt the methods and mindset of the opponents he criticizes.

\section{References}

Abdullah, M. Amin, (1995), Falsafah Kalam di Era Postmodernisme, Yogyakarta: Pustaka Pelajar.

Abu Dawud, (1935), Sunan Abi Dawud, Kairo: al-Maktabah al-Tijariyyah.

Al-Ghazali, Abu Hamid, (1996), Tahafut al-Falasifah, Mesir: Dar al-Ma'arif.

Al-Ghazali, Abu Hamid, (2000), Maqashid al-Falasifah, (Damaskus: Mathba'at al-Shabah. 
Al-Ghazali, Abu Hamid, (tt, tp), al-Munqidz min al-Dhalal.

DeBoer, T. J. \& Edward R. Jones, (1970), The History of Philosophy in Islam, London: LUZAC \& COMPANY LTD.

Dunya, Sulaiman, (1971), al-Haqiqah fi Nazhr al-Ghazali, Mesir: Dar al-Ma’arif.

Fakhry, Majid, (1997), A Short Introduction to Islamic Philosophy, Theology and Mysticism, (Oxford England: Oneworld Publications.

Frank Griffel, (2009), Al-Ghazali's Philosophycal Theology, (New York: Oxford University Press.

Goodman, Lenn Evan, (1978), “Did al-Ghazali Deny Causality?” dalam Studia Islamica, No. 47.

Hourani, George F., (1959), “The Chronology of Ghazali’s Writings” dalam JAOS, LXXX.

Ibnu Rushd, (1964) Tahafut al-Tahafut, Kairo : Dar al-Ma'arif.

Ibnu Rushd, (1972), Fashl al-Maqal wa al-Taqrir bayn al-Shari'ah wa al-Hikmat min al-Ittishal, Kairo : Dar al-Ma'arif.

Krarneaers, (1953), Shorter Encyclopedia of Islam, Leiden, tp.

Marmura, Michael E., (1981), "Al-Ghazali's Secound Causal Theory in the 17th Discussion of His Tahafut" dalam Islamic Philosophy and Misticism, New York.

Marmura, Michael E., (1989), "Al-Ghazali on Bodily Resurrection and Causality in Tahafut and the Iqtisad”, dalam Aligarh Journal of Islamic Thought, vol. I.

Marmura, Michael E., (2005), "Al-Ghazali” dalam The Camridge Companion to Arabic Philosophy, (Camridge: United Kingdom at University Press.

Michot, Jean R., (1993), La Pandemie Avicennienne au Vie/XIIe Seice Presentation, Arabica, T. 40. Facs. 3.

Muckle, J. T., (1933), “Introduction” dalam Algazel's Metaphysics: A Medieval Translation, Toronto.

Ricard M. Frank, (1994), Al-Ghazali and The Ash'arite School, (Durham: Duke University Press.

Shihadeh, (2016), Ayman, Doubts on Avicenna, Leiden: Brill.

Sheikh, M. Saeed, (1963), "al-Ghazali: Metaphisics" dalam History of Muslim Philosophy, (Germany: Allgauer Heimatverlag GmbH.

Sherif, Mohamed Ahmed, (1975), Ghazali’s Teory of Virtue, New York: State University of New York Press,

Watt, W. Montgomery, (1952) "The Authenticity of Works Attributed to al-Ghazali”, dalam JRAS. 